\title{
The effects of forest edge and nest height on nest predation in a U.K. deciduous forest fragment
}

Noah Atkin ${ }^{1}$ and Cris Banks-Leite ${ }^{2}$

${ }^{1}$ Imperial College London

${ }^{2}$ Affiliation not available

December 18, 2020 


\begin{abstract}
It has been previously hypothesised that nest predation is higher at forest edges. This has important conservation implications for the increasingly fragmented U.K. climax community. I aimed to test the generality of this edge effect in a mixed deciduous forest fragment which borders open grassland. Artificial nests containing a combination of quail and plasticine eggs were used, at ground and arboreal levels. I found an overall edge effect on nest predation rates, however this effect was not specifically seen in ground nests. Ground nests experienced significantly higher levels of predation than arboreal nests. I suggest this edge effect is due in part to the steep productivity gradient over the ecotone.
\end{abstract}

\title{
Introduction
}

Habitat fragmentation is the process whereby a large area of habitat is split into a number of smaller habitat patches, with a smaller total area (Wilcove, McLellan \& Dobson, 1986). Habitat fragmentation in the modern day is largely driven by anthropogenic land use change, such as urbanisation, deforestation and intensive agriculture. These dramatic changes expose pre-existing climax communities to artificial habitats, often with lower productivity (Ries et al., 2004). Anthropogenic-mediated fragmentation often results in unnatural and intricate shapes, increasing the proportion of the new habitat which is affected by the edge (Fig. 1). Habitat fragmentation significantly reduces the species richness of animals and plants across communities, through time-delayed but deterministic extinction of previously dominant species in a habitat - known as extinction debt (Haddad et al., 2015; Tilman et al., 1994). Given the continued increase in habitat fragmentation, and Haddad (2015)'s finding that $20 \%$ of remaining forest is within $100 \mathrm{~m}$ of the forest edge, it's important to understand the effects these edges can have on existing biological communities. 

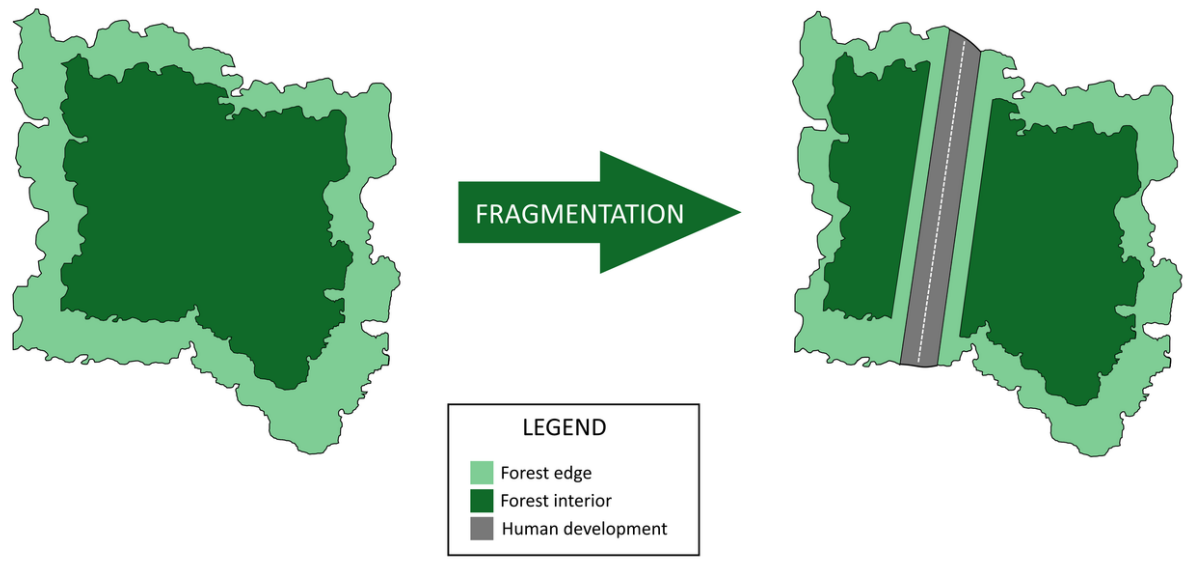

Figure 1: The process of human driven habitat fragmentation, whereby a large habitat is split into smaller sections each with a smaller area than the original, with a larger proportion of edge (Wilcove, McLellan \& Dobson, 1986).

Edge effects are the changes in community structure that are present at the boundary between two or more habitats (Yahner \& Scott, 1988). Edges, also known as ecotones, are affected by the abiotic conditions of both habitats, and the subsequent combination can affect ecosystem processes (Ries \& Sisk, 2004). The rate of some ecosystems processes have been shown to increase under the effect of edge-mediated abiotic factors, such as carbon sequestration. For example, it has been shown temperate forest growth and biomass increase with proximity to the forest edge (Cochrane \& Laurance, 2002). However, these same abiotic factors can also decrease certain ecosystem processes, such as decomposition (Harper et al., 2005). Edge environments tend to be drier and warmer than those of the interior due to wind exposure and increased insolation. These factors are drivers of decomposition and previous studies have shown decomposition increases with distance from the edge (Crockatt \& Bebber, 2014). Significant changes in these ecosystem processes are an indication of alteration to food web and community structure, and can be deleterious to endemic specialists (Petchey et al., 1999). As well as abiotic factors, biotic factors can also affect ecosystem processes at the for- 
est edge. Ecological generalists are more able to adapt to the varied conditions of edges, while edge effects are generally considered to have negative effects on existing specialist biological communities (Harrison \& Bruna, 1999). An increased proportion of these generalists can affect overall ecosystem functioning through degradation of underlying ecological processes, such as nest predation (Ries \& Sisk, 2004).

Increased nest predation as an edge effect was initially suggested as a general rule in 1978, and was hypothesised to be driven by increased bird population density at edges and may form a so-called "ecological trap" for nesting birds (Gates \& Gysel, 1978). This ecological trap is formed of 2 parts: i) The previously observed effect of nest predation increasing with nest density (Krebs, 1971), and ii) increased nest density at edges (Gates \& Gysel, 1978), which together form the cumulative edge effect on nest predation. While many previous studies have shown nest predation can increase with proximity to the forest edge, the universality of this rule has been challenged (Huhta, 1999). In a meta-analysis, Lahti (2001) found the hypothesis had been rejected in a majority of experiments, and the underlying causes of such an effect are not as simple as the ecological trap hypothesis suggests. It's been subsequently proposed that a nest predation edge effect is mediated by abiotic edge factors, such as the land use of the bordering habitat(Ries \& Sisk, 2004). For example, forest fragments bordering open grassland has been hypothesised to assist predators using linear geographic features such as edges as a foraging route (Rodewald, 2002). Geographic orientation is another edge factor which can exacerbate edge effects, and is rarely controlled for in edge effect studies. There is strong evidence to support the hypothesis that south-facing edges in the Northern hemisphere suffer larger edge effects, due to increased insolation (Ries et al., 2004). Similarly temporal factors, such as seasonality and annual changes in temperature have been seen to play a role in edge effects, and some edge responses can even reverse depending on the season, although this is rare (Ries et al., 2004). All of these abiotic edge factors interact 
with the native biota and can create unique combinations of edge effects. Given the vast variability in these edge factors worldwide, and that predator composition and behaviour differs between regions, this suggests previous findings on edge-mediated nest predation may not be applicable to new experimental environments (Thompson, 2007). Particularly given that most nest predation experiments do not identify predators responsible for the effect (Whyte, Didham \& Briskie, 2005).

Edge effects may have significant impacts for birds in the United Kingdom (U.K.). Native forest cover in the U.K. has been declining since the early Holocene, and the remaining areas are increasingly fragmented (Whitehouse \& Smith, 2010). Historical forest cover in the U.K. is inherently difficult to calculate, as undocumented prehistoric land conversion from forest to subsistence farming destroyed most of the native climax community and replaced it with artificial habitats, such as heath and moorland (Pauliet, Ennos \& Golding, 2005). From the 19th century onward, land use change in temperate regions has trended away from subsistence farming towards urbanisation and intensive agriculture. These trends have only spread to tropical regions in the last 50 years, which has resulted in a loss of $1 / 3$ of the world's forested areas (Haddad et al., 2015). Urbanisation has been responsible for vast deforestation in sub-Saharan Africa, as urbanisation drives up demand for fuel wood (Chidumayo, 1984). While intensive agriculture is the current main driver of deforestation in the Amazon rainforest, due to the economic incentives of cattle ranching (Sparovek et al., 2012). Despite these global trends, forest cover in the U.K. has been increasing since the 1920s (DEFRA, 2013). However, the majority of original forest cover has been replaced with non-native conifer monocultures. These monocultures do not provide the same ecological function as native forests and further fragments the U.K. deciduous climax community (Liu, Kuchma \& Krutovsky, 2018). This high level of fragmentation is particularly problematic for the contained biological communities, as edge effects increase as a function of habitat fragmen- 
tation (Vetter, Rücker \& Storch, 2013). In addition, U.K. forest fragments often border open farming landscapes due to economic incentives for intensive agriculture (Pauliet, Ennos \& Golding, 2005). These open landscapes provide a "sharp" border to the forest, and are capable of supporting high densities of opportunistic generalist predators, which can then prey on the exposed edges (Lahti, 2001). These risks are particularly high for increasingly endangered U.K. ground nesting birds, given the predominantly terrestrial morphology of opportunistic generalist predators.

Research on the effects of edges on nest predation in temperate ecotones have largely been performed in the U.S.A. (Lahti, 2001). As U.K. predator composition and behaviour differs greatly from North America, this suggests findings from these studies may not be applicable to U.K. deciduous woodland (Thompson, 2007). This study aims to examine whether the previously hypothesised generality of edge effect mediated nest predation applies to a U.K. mixed deciduous forest fragment, at both ground and arboreal levels. It was hypothesised that predation rates would increase with proximity to the forest edge regardless of height. Given the previous mixed effects of edge on nest predation, a large scale study seemed appropriate to examine the effect on the forest fragment and this experiment is the first of its scale to study these effects in the U.K.

Many previous studies on nest predation using artificial nests have been unable to identify predators responsible for the predation, despite predator identity being hypothesised as a significant driver of nest predation at forest edges (Whyte, Didham \& Briskie, 2005). Therefore, in this study, predators were identified using bite marks left on plasticine eggs. This should provide insight into the composition of predators that prey on forest edges in deciduous woodland and elucidate pest control priorities around these fragmented areas. 


\section{Methods}

\section{Study Site}

The experiment took place at Silwood Park, Imperial College London $\left(51^{\circ} 24^{\prime} 30.6^{\prime} \mathrm{N}\right.$ $0^{\circ} 38^{\prime} 31.3^{\prime \prime} \mathrm{W}$ ) in a $200 \mathrm{~m} \times 350 \mathrm{~m}$ stretch of mixed deciduous woodland which borders open grassland (Fig. 2). An experiment focusing on the breeding ecology of blue tits was also being conducted in the woodland using artificial nesting boxes and marked trees. No trees were shared between the two experiments, and a minimum of $10 \mathrm{~m}$ from each marked tree was maintained to avoid bias.

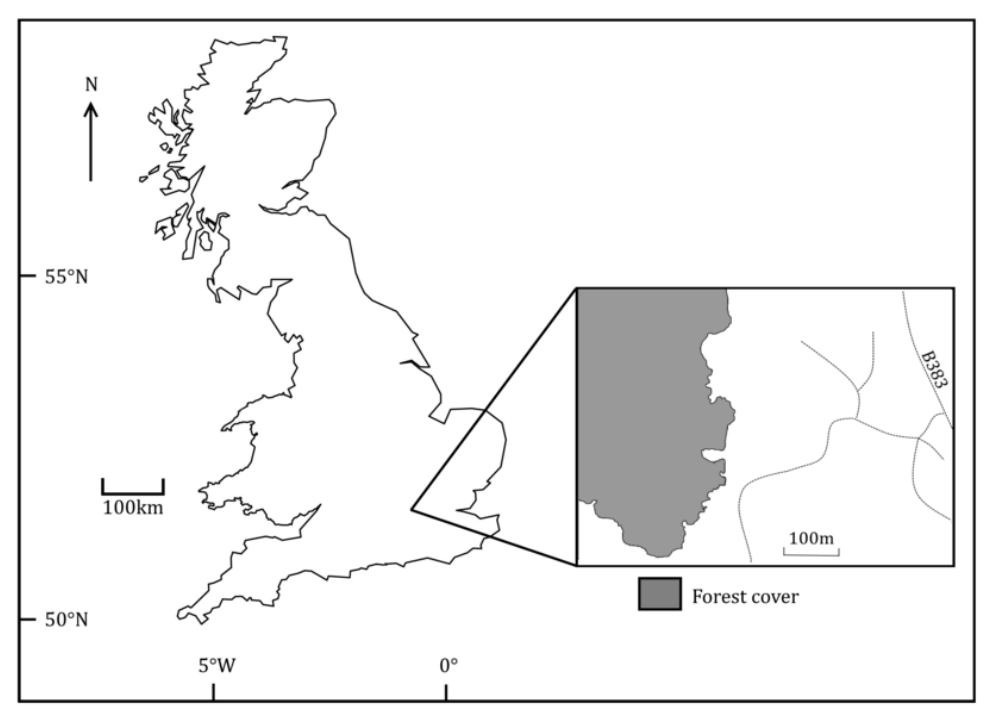

Figure 2: Map of Great Britain showing the location of the study site at Silwood Park, Berkshire 


\section{Pilot Study}

A pilot study was performed for 2 weeks in March 2019 using 8 artificial nests to examine basic questions about predator behaviour and whether the experiment was suitable for a larger study. Specifically, the pilot study aimed to answer i) whether predators in the forest would be able to locate artificial nests and ii) whether the presence of artificial plasticine eggs would significantly affect predation rates. The pilot examined predation rates on artificial nests containing 1 quail and 1 plasticine egg, using nests containing only 1 quail egg as a control. This revealed nests containing plasticine eggs had significantly higher predation rates $\left(\chi^{2}=17.681, p<0.0001\right)$, suggesting additional methods would be required to reduce olfactory cues given off by the artificial eggs. Full methods and results for the pilot study can be read in the supplementary information (S1).

\section{Power Analysis}

To estimate the number of experimental nests I needed, I carried out a power analysis. The pilot study was too limited in number of replicates to generate an accurate estimate of the effect size of edge effects, so effect sizes were gathered from a variety of papers who

had performed similar experiments (Kotze \& Lawes, 2007; Cooper \& Francis, 1998; Burkey, 1993; Temple \& Cary, 1988). An average was taken which indicated a low effect size ( $\mathrm{w}=$ 0.256). Using the default values of $\mathrm{p}=0.05$ and power $=0.8$, this showed that $\mathrm{N}=119.8$, meaning 120 nests would be used for the full experiment.

\section{Materials and Methods}

The experiment was run for 2 weeks from 13-26 May 2019. 120 artificial birds nests made from conifer leaves and metal wire were used in this experiment. 30 trees were selected at the forest edge and interior. Trees at the forest edge were selected using a linear transect across the forest edge, with trees selected at $10 \mathrm{~m}$ intervals. Due to the size of the fragment, 
a linear transect was unable to be used for the forest interior. After arbitrarily choosing an initial tree in the centre of the interior, trees were chosen using a random number generator, which generated a bearing and a tree in that bearing was chosen if i) it was not within $5 \mathrm{~m}$ of any other tree and ii) if it was still within the forest interior. Each tree contained 2 nests, 1 ground and 1 arboreal. In total, 60 nests were placed at the forest edge $(<10 \mathrm{~m}$ away from the edge) and remaining 60 were placed at the forest interior ( $>100 \mathrm{~m}$ away from the edge). Where necessary, arboreal nests were attached to trees using steel wire. Each tree was a minimum of $5 \mathrm{~m}$ away from any other selected tree, and no attempts were made to disguise or hide the nests. Since nest markers may cue predators to the presence of the nest, no nest markers were used.

3 eggs were placed in each nest, 1 quail egg and 2 plasticine eggs. The pilot study indicated a high risk of artificial eggs being removed or destroyed, for this reason 2 plasticine eggs were used instead of 1 (S1). Plasticine eggs were made by hand to have the dimensions of a reference quail egg $(3.5 \mathrm{~cm}$ long, $2.8 \mathrm{~cm}$ diameter $)$, and were aerated for 3 days after manufacture to mitigate the strong scent. To reduce the scent further, plasticine eggs were coated with a thin layer of rubber (PlastiDip $\left.{ }^{\circledR}\right)$ before aeration, which has been shown to reduce overestimation of mammalian predation rates (Purger et al., 2012). Eggs were marked on their base to identify the nest they were placed in, to assists in cases where an egg was removed from the nest but able to be recovered. A nest was considered to be predated if any of the eggs were damaged or missing. Nests were examined daily and predated eggs were replaced. Predator tooth marks in the plasticine eggs were identified using reference photos of woodland predators skulls. For spatial analysis, nest locations were recorded using a Garmin eTrex 10, and co-ordinates were averaged from 5 measurements over the course of 1 day for increased accuracy. 


\section{Statistical Analyses}

The statistical effect of edge and nest height was measured using generalized linear model, using a binomial distribution which measured the overall nest predation rates over the 2 week period. The response variable was the proportion of days a nest was predated, and the explanatory variables were nest height and nest location. Given the previous inconsistency between nest predation experiments, it seemed appropriate to calculate a comparable effect size of an edge effect for future reference. Cohen's $d$ was calculated from the generalized linear model output using the sos package in R (Graves, Dorai-Raj \& Francois, 2017). Mantel tests were performed to examine the role spatial autocorrelation plays in nest predation at the edge and interior. All statistical analyses was performed in R (R Core Team, 2019). A significance level of $\mathrm{p}<0.05$ was used in all tests.

\section{Results}

Proximity to edge was shown to significantly increase nest predation rates. The generalized linear model showed when accounting for all nests, the effect of edge on nest predation was statistically significant $(\mathrm{p}=0.007$, $\mathrm{z}$-value $=2.687)$. Regardless of proximity to edge, ground nests experienced significantly higher predation rates than arboreal nests $(\mathrm{p}<0.001$, z-value $=-19.239)$. There was no significant interaction effect between nest height and edge $(\mathrm{p}=$ 0.16). When analysed separately, the effect of edge on nest predation in arboreal nests was found to be significant $(\mathrm{p}=0.01, \mathrm{z}$-value $=2.576)$, but not for ground nests $(\mathrm{p}=0.121$, $\mathrm{z}$-value $=1.549)$. It should also be noted that every ground nest was predated at least once during the course of the experiment. The overall edge effect size on ground and arboreal nests was calculated to be $d=0.245$, indicating a small effect of edge proximity on nest predation. 


\section{Effect of edge on nest predation}

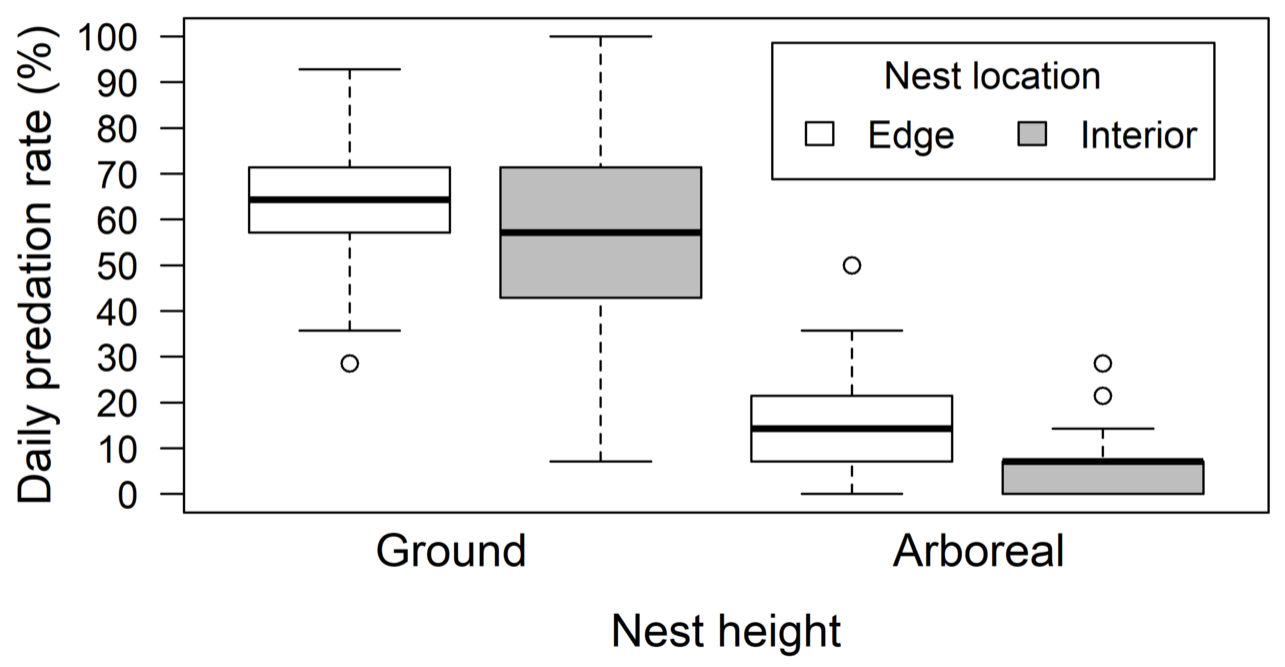

Figure 3: Differences in daily predation rates at ground and arboreal levels. Arboreal nest predation rates were significantly lower than ground nests $(\mathrm{p}<0.001$, z-value $=-19.239)$. Nest location was also found to be significant, albeit with a smaller effect size $(p=0.007$, z-value $=2.687)$

Mantel tests were performed separately for ground and arboreal nests due to the significant differences between their predation rates and predator composition. Ground nests did not show any spatial autocorrelation $(\mathrm{r}=0.024, \mathrm{p}=0.273)$ (Fig. 4), however predation in arboreal nests revealed some level of spatial auto-correlation $(\mathrm{r}=0.089, \mathrm{p}=0.025)$ (Fig. 5). The observed correlation between arboreal nests, $\mathrm{r}=0.089$, suggests a slight positive association, so smaller differences in predation rates are generally seen among pairs of arboreal nests that are closer to each other. 


\section{Daily ground nest predation rates}

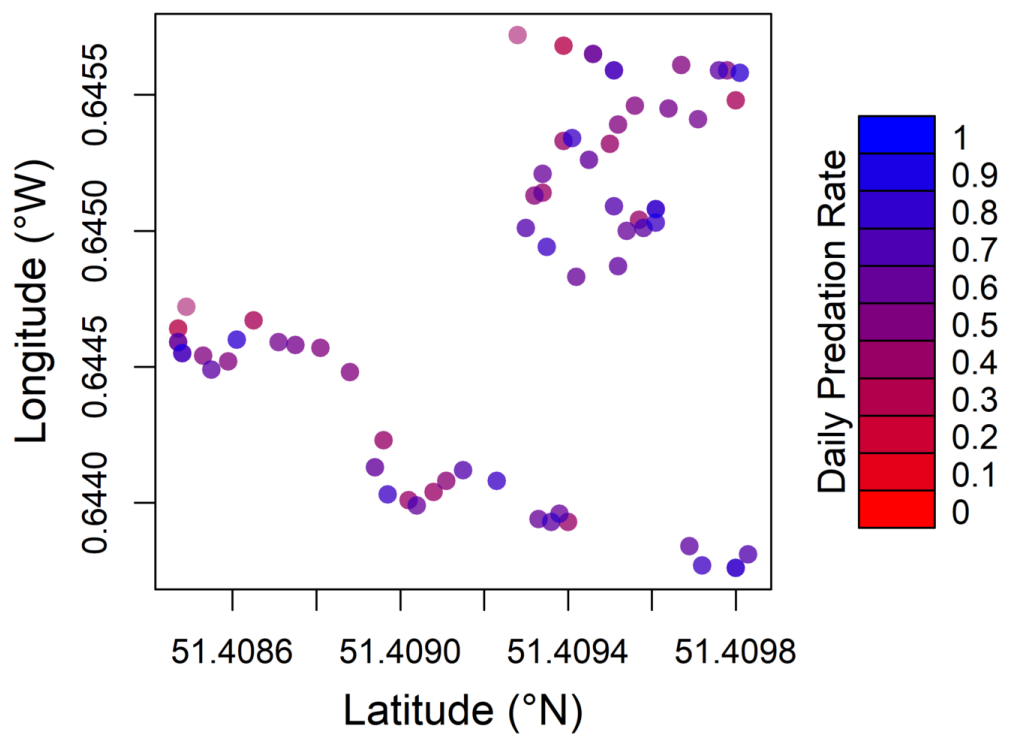

Figure 4: Geographic representation of ground nests and their Daily Predation Rates (DPR). A mantel test indicated no significant association between nest adjacency and predation rates $(\mathrm{r}=0.024, \mathrm{p}=0.273)$.

\section{Daily arboreal nest predation rates}

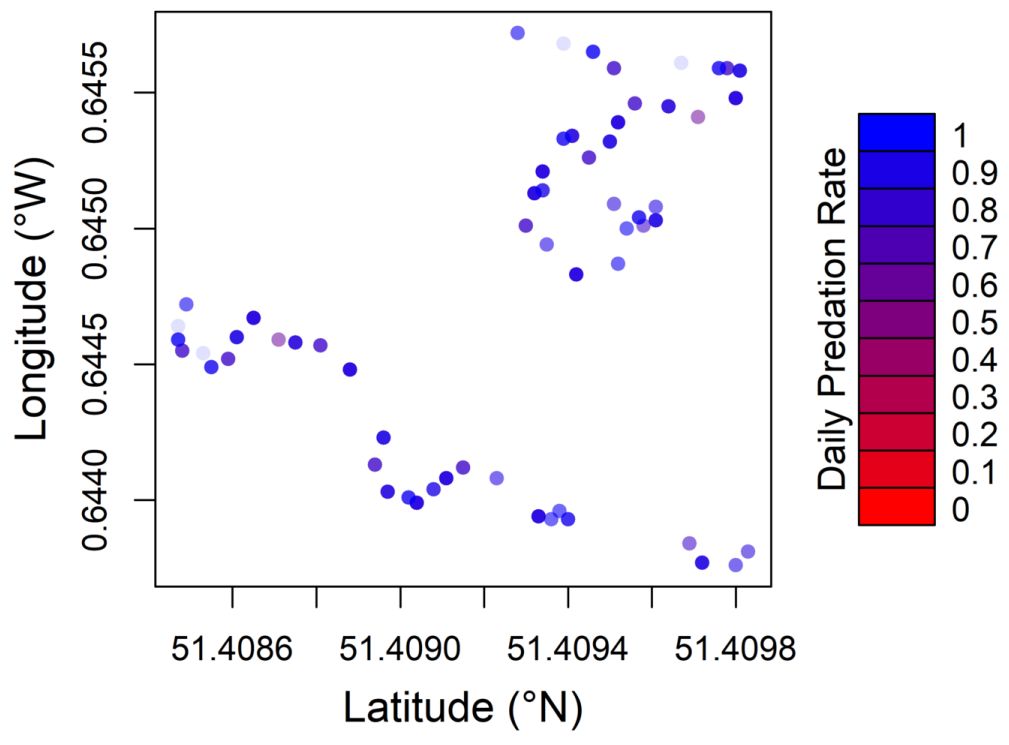

Figure 5: Geographic representation of arboreal nest location and their daily predation rates. A mantel test indicated a significant association between nest adjacency and predation rates, with a small effect size $(r=0.089, \mathrm{p}=0.025)$ 
6 types of nest predator were identified. The majority of the identified predation came from mice (Muridae spp.), which accounted for $47.8 \%$ of predation across both heights, and $50.7 \%$ of ground nest predation (Fig. 6). Ground nests were also preyed upon by hedgehogs (Erinaceus europaeus, 4.1\%), rats (Rattus spp., 12.3\%), badgers (Meles meles, 24.1\%) and occasionally foxes (Vulpes vulpes, $8 \%$ ). Most of the identified arboreal nest predation is due to bird predation $(92.9 \%)$, however the high rate of missing eggs in arboreal nests means the majority of arboreal predation is unable to be attributed to a specific ntified predator. Over both heights sampled, the majority of the predations were unable to be identified (64.6\%), most commonly due to eggs being unable to be located (53.9\%), and a considerable portion were destroyed beyond recognition $(10.7 \%)$.

\begin{tabular}{|lllllllllll|}
\hline Distance & $\begin{array}{l}\text { Nest } \\
\text { Height }\end{array}$ & $\begin{array}{l}\text { \% Nests } \\
\text { Attacked }\end{array}$ & DPR & Mouse & Hedgehog & Rat & Badger & Fox & Bird & Unknown \\
& Ground & $100.00 \%$ & 0.63 & 41 & 0 & 18 & 27 & 13 & 0 & 164 \\
$>10 \mathrm{~m}$ & Ground & $100.00 \%$ & 0.57 & 58 & 8 & 6 & 20 & 4 & 0 & 145 \\
Combined & Ground & $100.00 \%$ & 0.60 & 99 & 8 & 24 & 47 & 17 & 0 & 309 \\
$<10 \mathrm{~m}$ & Arboreal & $80.00 \%$ & 0.13 & 1 & 0 & 0 & 0 & 0 & 8 & 46 \\
$>100 \mathrm{~m}$ & Arboreal & $63.33 \%$ & 0.1 & 0 & 0 & 0 & 0 & 0 & 5 & 27 \\
Combined & Arboreal & $71.67 \%$ & 0.115 & 1 & 0 & 0 & 0 & 0 & 13 & 73 \\
Total & & $85.83 \%$ & 0.36 & 100 & 8 & 24 & 47 & 17 & 13 & 382 \\
\end{tabular}

Figure 6: Percentage of ground and arboreal nests predated upon, their Daily Predation Rate (DPR), and the identity of predators responsible for predation. 'Unknown refers to nest predations where the eggs were destroyed beyond recognition, or unable to be located. 30 nests were sampled at each location and height combination. 


\section{Discussion}

At the experiment site there was an overall significant effect of nest predation at the forest edge compared to the interior, however our hypothesis was incorrect that this would be effect would be present on ground nests. As previously mentioned, the universality of a linear edge effect on nest predation has been effectively disproved. As Lahti (2001) showed, the majority of nest predation experiments show no significant difference between edge and interior, which may be because the gradient of predation rates is not always linear. Previous research has indicated that nest predation edge effects can follow unusual, eratic gradients at intermediate distances from the edge (Whyte, Didham \& Briskie, 2005; Murcia, 1995). The varied nature of these previous findings is suggested to be due to interactions between multiple abiotic edge factors, causing unique microclimates at various distances from the edge. Hence the focus should be on the abiotic and biotic factors specific to this edge and interior which may interact to cause such an edge effect on arboreal nests.

\section{Abiotic Edge Factors Affecting Predation}

Edge contrast has previously been hypothesised to exaggerate edge effects (Ries \& Sisk, 2004). The bordering habitat to the examined forest fragment is open grassland, which has a comparatively low productivity compared to forests (Lahti, 2001). Previous studies have indicated that the steepness of the gradient in productivity over an ecotone may play a role in nest predation, and that such an effect is exaggerated by high levels of habitat fragmentation (Angelstam, 1986). Lahti (2001)'s meta-analysis did not show such an effect, however it did show that a edge effect on nest predation is significantly less likely where 
the gradient in productivity is shallow (e.g grassland and agricultural land). This suggests steepness of ecotone productivity gradients may only increase nest predation conditionally, subject to other factors. The large productivity contrast in this study between woodland and open grassland may partially explain increased nest predation at the edge, however other U.K. forest fragments with smaller productivity contrasts will need to be examined before a casual effect can be established.

The effect of orientation may not have played a significant role on the observed edge effect in this study. The experimental forest edge is east facing and previous studies on the effect of orientation on edges focus on North-South orientation. Current understanding of orientations impact on edges suggests east-west orientation does not significantly influence edge effects (Ries et al., 2004).

There may however be a temporal impact on this experiment, as the study was only carried out for 2 weeks post-spring, where U.K. bird populations are near their peak (DEFRA, 2018). Previous studies in Scotland have shown significant seasonality in nest predation rates around spring. Nest predation rates were shown to peak in late April, and then slowly decline until late June (Malzer \& Helm, 2015). If this seasonal predation effect is also seen in England, it may help account for the unusually high levels of predation seen in this experiment. However it should be noted that although Malzer \& Helm (2015) found an overall effect of season on nest predation, it did not influence the edge effect, which was constant year round.

\section{Predator idendity}

The main predators of ground nests identified in this study were mice, and other nest predation experiments have identified mice as a significant predator of artificial nests (Whyte, Didham \& Briskie, 2005; Nour, Matthysen \& Dhondt, 1993). These results are in contrast to previous findings that cast doubt on rodents willingness to predate quail eggs in artificial 
nest experiments (Niehaus et al., 2003). Natural experiments in the U.S. have found over $75 \%$ of ground nest predations are caused by terrestrial rodents (Sanders \& Chalfoun, 2019). These results are slightly higher than our experiment (63\%), however my results underline the ubiquity of the significant impacts rodents have on ground nesting bird communities. Particularly given that nest predation is the most significant cause of nest failure (Lahti, 2001). Mouse-driven nest predation decreased with proximity to the edge, as $58.6 \%$ of mouse depredations took place in the forest interior. This may be due to the populations dynamics and range size of mice in forested regions. Previous studies in tropical habitats have suggested that forest edges are a more preferable habitat to various species of mice, particularly over ecotones with sharp productivity gradients (López-Barrera, 2003). Generally mouse population density is lower in the interior of forests, this is suggested to be due to the edge being a richer habitat which could be modelled using an ideal despotic distribution (IDD) (Wolf \& Batzli, 2002). However it's also been shown small forest fragment size has positive impacts on the fitness associated traits of mice, such as body size (Díaz, Santos \& Tellería, 1999). In this particularly small forest fragment it may be that the distance to edge to maximise mouse fitness is $>10 \mathrm{~m}$, and the beneficial abiotic factors of the edge reach further into the forest than the edge as defined in this study.

\section{Autocorrelation of arboreal nest locations}

One of the more unusual results from this experiment is the spatial autocorrelation between arboreal nest proximity and location, which is not present on ground nests. Particularly given that the dispersal constraints of terrestrial predators are usually larger than those of arboreal predators. As there is a smaller diversity of arboreal predators in the U.K., the autocorrelation could be due to a smaller number of individuals predating the nests, limited by their dispersal constraints. In conjunction, the ground nests were predated on by more 
individuals, disguising individual dispersal patterns. This could be an avenue of future study, however it should be noted the spatial autocorrelation was quite weak $(\mathrm{r}=0.089)$, so the result may not be ecologically significant.

\section{Predation intensity}

Predation intensity at ground levels were significantly larger than those in arboreal nests, which supports some previous studies (Whyte, Didham \& Briskie, 2005; Piper \& Catterall, 2004), although this result is not universal (Yahner \& Mahan, 1999). Ground nest predation rates in this experiment were very high compared to other artificial nest experiments, regardless of nest location (Whyte, Didham \& Briskie, 2005). There are many potential reasons for this effect. As previously mentioned, it may be due to an annual seasonal effect of spring increasing predation rates nationwide (Malzer \& Helm, 2015). The sharp edge of the forest may also play a role. The bordering open grassland is capable of supporting high densities of opportunistic generalist predators which can follow linear foraging routes of the edge. However, while this may have guided mesopredators to edge nests, but does not adequately explain the high interior predation rates (Lahti, 2001).

I suggest that predator intelligence may be responsible. The hypothesis that predators can learn the locations of artificial nests has been tested previously using arboreal nests. Yahner \& Mahan (1999) examined avian and non-avian predation between fixed-location and randomly relocated nests, and found no such learning effexct. Similar analysis of learning behaviour has been performed by Anglestam (1986), who used cryptic nests in edge predation experiments, but was also unable to find a significant effect of learning. However, most learning studies utilise arboreal nests, and a previous study on ground nests using chicken eggs in a heavily fragmented forest indicated the predators had become habituated to the nests, and sought them out (Yahner \& Mahan, 1996). This risk is particularly prevalent 
in small isolated forest fragments, where populations are small and the rate of migration is low (Krebs, 2002; Yahner \& Mahan, 1999). In such a small area, mammalian predators can learn to associate olfactory cues with artificial nests, and previous studies have indicated that mammalian predators already use olfactory cues to locate artificial nests containing plasticine eggs (Purger et al., 2012). While plasticine scent was controlled for in this study, the nests were manufactured from conifer leaves, which are not present in the experimental forest fragment, and their cryptic scent and appearance which may provide routes for habituation. Population densities of predator species in the forest fragments should be examined in future study to examine evidence of possible learning behaviour, and hence the usefulness of artificial nest experiments in this small forest fragment.

Another possible mechanism for this unusually high level of predation is the mesopredator release effect. In the absence of large predators, mid-ranking predators can take over the ecological role of apex predators in the food web (Soule et al., 1988). In unfragmented habitats, apex predators can exert top down ecological control of an ecosystem, which has indirect benefits on prey populations by suppressing mid-level predators (Elmhagen \& Rushton, 2007). However, larger species are more vulnerable to habitat fragmentation due to their larger range size, meaning mesopredator release may become a growing problem for an increasingly fragmented U.K. forest habitat (Prugh et al., 2009). Future study in this area which should aim to examine the populations of apex predators and mesopredators in this woodland, and examine whether the mesopredator release hypothesis is a good fit for these findings. If so, apex predator control measures may be a valid conservation action for ground nesting bird populations through top-down control of rodent populations. 


\section{Limitations}

Artificial nest experiments have inherent flaws, and the results are not always directly applicable to wild bird populations. Artificial nests can overestimate predation rates, by attracting different predators and may not mimic the seasonal variation in predation rates observed in natural nest experiments (Zanette, 2002; Weidinger, 2008). However, comparisons between nest height and edge proximity to examine the factors that drive predation are useful model of underlying predator behaviour, and continue to be a useful tool in avian nesting success studies.

\section{Acknowledgements}

I would like to thank Cristina Banks-Leite of Imperial College London for help and advice regarding the pilot study, statistical analysis and invaluable guidance throughout the project. I would also like to thank the technical staff at Silwood Park for their assistance using the GPS unit for spatial analysis. Many thanks to the Department of Life Sciences at Imperial College London, and specifically the Biology Undergraduate department, without whom this project could not be possible. 


\section{Supplementary Material}

A pilot study was undertaken for 2 weeks in March 2019 using 8 artificial nests to answer questions about predator behaviour and to discover whether the suggested experimental protocols were suitable for a larger study. The pilot aimed to answer 2 main questions: Are predators in the forest would locate and predate upon the nests at ground and arboreal levels, and does the presence of artificial plasticine eggs significantly affect predation rates? While plasticine eggs are very malleable and allow for the identification of predators through bite marks, some studies have shown that the olfactory cues given off by plasticine eggs can lead to an overestimation of mammalian nest predation (Batáry, 2008).

\section{Methods}

1 quail egg and 1 plasticine egg was placed in half of the nests, and the remaining nests contained only 1 quail egg as a control. Plasticine eggs were manufactured by hand to have the dimensions of a reference quail egg ( $3.5 \mathrm{~cm}$ long, $2.8 \mathrm{~cm}$ diameter), and no attempt was made to prevent olfactory cues. The nests were split equally between ground and arboreal locations. Ground nests were placed in, or at the base of trees, where each tree is more than $15 \mathrm{~m}$ away from any other selected tree. Arboreal nests were mounted to trees using steel wire where necessary, and were all accessible via branches capable of supporting the weight of predators. No attempts were made to disguise, or hide the nests either at ground or arboreal levels. 4 nests were placed in the forest interior and the remaining 4 were placed on the forest edge. For the purposes of the pilot, forest edge was defined as within $10 \mathrm{~m}$

of the edge of the forest, and forest interior was $>100 \mathrm{~m}$ away from any edge. Nests were considered to be predated if they were missing, broken or otherwise interfered with (e.g bite marks). Nests were examined daily for predation.

The statistical analysis used $\chi^{2}$ tests were performed using $\mathrm{R}$ to examine the observed preda- 
tion from nests containing plasticine eggs to the expected predation (control nests) (R Core Team, 2019).

\section{Results}

The pilot study found no significant difference between ground and arboreal nests $\left(\chi^{2}=\right.$ 0.210, $\mathrm{p}=0.647)$ indicating the full study can use ground and arboreal nests, and that the arboreal nests are being predated. The pilot did however find a significant difference in predation rates between nests with and without the plasticine eggs $\left(\chi^{2}=17.681, \rho<0.001\right)$, possibly due to the olfactory cues the plasticine was emitting, indicating either a different material for artificial eggs should be used, or steps should be taken to reduce the smell. It should also be noted that every day of the trial, at least 1 plasticine egg was completely eviscerated preventing predator identification. 


\section{References}

Angelstam, P. (1986) Predation on Ground-Nesting Birds' Nests in Relation to Predator Densities and Habitat Edge. Oikos. [Online] 47 (3), 365. Available from: doi:10.2307/3565450.

Batáry, A.T.\& P.P.\& P. (2008) Dummy birds in artificial nest studies: an experiment with Red-backed ShrikeLanius collurio. Bird Study. [Online] 55 (3), 329-331. Available from: doi:10.1080/00063650809461539.

Burkey, T.V. (1993) Edge effects in seed and egg predation at two neotropical rainforest sites. Biological Conservation. [Online] 66 (2), 139-143. Available from: doi:10.1016/00063207(93)90145-q.

Chidumayo, E.N. (1984) Urbanisation and deforestation in Zambia.. Desertification Control Bulletin. 9.

Cochrane, M.A. \& Laurance, W.F. (2002) Fire as a large-scale edge effect in Amazonian forests. Journal of Tropical Ecology. [Online] 18 (3), 311-325. Available from: doi:10.1017/s0266467402002237.

Cooper, D.S. \& Francis, C.M. (1998) Nest predation in a Malaysian lowland rain forest. Biological Conservation. [Online] 85 (1-2), 199-202. Available from: doi:10.1016/s00063207(97)00118-3.

Crockatt, M.E. \& Bebber, D.P. (2014) Edge effects on moisture reduce wood decomposition rate in a temperate forest. Global Change Biology. [Online] 21 (2), 698-707. Available from: doi:10.1111/gcb.12676.

DEFRA (2013) Government Forestry and Woodlands Policy Statement. [Online]. DEFRA. Available from: https://assets.publishing.service.gov.uk/government/ uploads/system/uploads/attachment_data/file/221023/pb13871-forestry-policy- 
statement.pdf .

DEFRA (2018) Wild Bird Populations in the UK, 1970 to 201\%. [Online]. Available from: https://assets.publishing.service.gov.uk/government/uploads/system/uploads/ attachment_data/file/754432/UK_Wild_birds_1970-2017_FINAL__002_.pdf .

Díaz, M., Santos, T. \& Tellería, J.L. (1999) Effects of forest fragmentation on the winter body condition and population parameters of an habitat generalist the wood mouse Apodemus sylvaticus: a test of hypotheses. Acta Oecologica. [Online] 20 (1), 39-49. Available from: doi:10.1016/s1146-609x(99)80014-9.

Elmhagen, B. \& Rushton, S.P. (2007) Trophic control of mesopredators in terrestrial ecosystems: top-down or bottom-up?. Ecology Letters. [Online] 10 (3), 197-206. Available from: doi:10.1111/j.1461-0248.2006.01010.x.

Gates, J.E. \& Gysel, L.W. (1978) Avian Nest Dispersion and Fledging Success in Field-Forest Ecotones. Ecology. [Online] 59 (5), 871-883. Available from: doi:10.2307/1938540.

Graves, S., Dorai-Raj, S. \& Francois, R. (2017) Package 'sos'. [Online]. Available from: https://cran.r-project.org/web/packages/sos/sos.pdf.

Haddad, N.M., Brudvig, L.A., Clobert, J., Davies, K.F., et al. (2015) Habitat fragmentation and its lasting impact on Earth's ecosystems. Science Advances. [Online] 1 (2), e1500052. Available from: doi:10.1126/sciadv.1500052.

Harper, K.A., Macdonald, S.E., Burton, P.J., Chen, J., et al. (2005) Edge Influence on Forest Structure and Composition in Fragmented Landscapes. Conservation Biology. [Online] 19 (3), 768-782. Available from: doi:10.1111/j.1523-1739.2005.00045.x.

Harrison, S. \& Bruna, E. (1999) Habitat fragmentation and large-scale conservation: what do we know for sure?. Ecography. [Online] 22 (3), 225-232. Available from: doi:10.1111/j.1600- 
0587.1999.tb00496.x.

Huhta, E. (1999) Breeding Success of Pied Flycatchers in Artificial Forest Edges: The Effect of a Suboptimally Shaped Foraging Area. The Auk. [Online] 116 (2), 528-535. Available from: doi:10.2307/4089385.

Kotze, D.J. \& Lawes, M.J. (2007) Viability of ecological processes in small Afromontane forest patches in South Africa. Austral Ecology. [Online] 32 (3), 294-304. Available from: doi:10.1111/j.1442-9993.2007.01694.x.

Krebs, J.R. (1971) Territory and Breeding Density in the Great Tit Parus Major L.. Ecology. [Online] 52 (1), 2-22. Available from: doi:10.2307/1934734.

Krebs, J.R. (2002) Optimal Foraging Predation Risk and Territory Defence. Ardea. [Online] 38-90, 83-90. Available from: doi:10.5253/arde.v68.p83.

Lahti, D.C. (2001) The "edge effect on nest predation" hypothesis after twenty years. Biological Conservation. [Online] 99 (3), 365-374. Available from: doi:10.1016/s0006$3207(00) 00222-6$.

Liu, C.L.C., Kuchma, O. \& Krutovsky, K.V. (2018) Mixed-species versus monocultures in plantation forestry: Development benefits, ecosystem services and perspectives for the future. Global Ecology and Conservation. [Online] 15, e00419. Available from: doi:10.1016/j.gecco.2018.e00419.

López-Barrera, F. (2003) Edge effects in a forest mosaic: implications for oak regeneration in the Highlands of Chiapas, Mexico.. PhD thesis. University of Edinburgh.

Malzer, I. \& Helm, B. (2015) The Seasonal Dynamics of Artificial Nest Predation Rates along Edges in a Mosaic Managed Reedbed Csaba Moskát (ed.). PLOS ONE. [Online] 10 (10), e0140247. Available from: doi:10.1371/journal.pone.0140247. 
Murcia, C. (1995) Edge effects in fragmented forests: implications for conservation. Trends in Ecology 85 Evolution. [Online] 10 (2), 58-62. Available from: doi:10.1016/s0169$5347(00) 88977-6$.

Niehaus, A.C., Heard, S.B., Hendrix, S.D. \& Hillis, S.L. (2003) Measuring Edge Effects on Nest Predation in Forest Fragments: Do Finch and Quail Eggs Tell Different Stories?. The American Midland Naturalist. [Online] 149 (2), 335-343. Available from: doi:10.1674/00030031(2003)149[0335:meeonp]2.0.co;2.

Nour, N., Matthysen, E. \& Dhondt, A.A. (1993) Artificial nest predation and habitat fragmentation: different trends in bird and mammal predators. Ecography. [Online] 16 (2), 111-116. Available from: doi:10.1111/j.1600-0587.1993.tb00063.x.

Pauliet, S., Ennos, R. \& Golding, Y. (2005) Modeling the environmental impacts of urban land use and land cover change - a study in Merseyside UK. Landscape and Urban Planning. [Online] 71 (2-4), 295-310. Available from: doi:10.1016/s0169-2046(04)00083-0.

Petchey, O.L., McPhearson, P.T., Casey, T.M. \& Morin, P.J. (1999) Environmental warming alters food-web structure and ecosystem function. Nature. [Online] 402 (6757), 69-72. Available from: doi:10.1038/47023.

Piper, S.D. \& Catterall, C.P. (2004) Effects of edge type and nest height on predation of artificial nests within subtropical Australian eucalypt forests. Forest Ecology and Management. [Online] 203 (1-3), 361-372. Available from: doi:10.1016/j.foreco.2004.08.005.

Prugh, L.R., Stoner, C.J., Epps, C.W., Bean, W.T., et al. (2009) The Rise of the Mesopredator. BioScience. [Online] 59 (9), 779-791. Available from: doi:10.1525/bio.2009.59.9.9. Purger, J.H.J., Kurucz, K., Tóth, Ádám \& Batáry, P. (2012) Coating plasticine eggs can eliminate the overestimation of predation on artificial ground nests. Bird Study. [Online] 59 (3), 350-352. Available from: doi:10.1080/00063657.2012.684550. 
R Core Team, T. (2019) R: A Language and Environment for Statistical Computing. [Online]. Vienna, Austria, R Foundation for Statistical Computing. Available from: https://www.Rproject.org.

Ries, L., Fletcher, R.J., Battin, J. \& Sisk, T.D. (2004) Ecological Responses to Habitat Edges: Mechanisms Models, and Variability Explained. Annual Review of Ecology, Evolution, and Systematics. [Online] 35 (1), 491-522. Available from: doi:10.1146/annurev.ecolsys.35.112202.130148.

Ries, L. \& Sisk, T.D. (2004) A predictive model of edge effects. Ecology. [Online] 85 (11), 2917-2926. Available from: doi:10.1890/03-8021.

Rodewald, A.D. (2002) Nest Predation in Forested Regions: Landscape and Edge Effects. The Journal of Wildlife Management. [Online] 66 (3), 634. Available from: doi:10.2307/3803130.

Sanders, L.E. \& Chalfoun, A.D. (2019) Mechanisms underlying increased nest predation in natural gas fields: a test of the mesopredator release hypothesis. Ecosphere. [Online] 10 (5), e02738. Available from: doi:10.1002/ecs2.2738.

Soule, M.E., Bolger, D.T., Alberts, A.C., Wrights, J., et al. (1988) Reconstructed Dynamics of Rapid Extinctions of Chaparral-Requiring Birds in Urban Habitat Islands. Conservation Biology. [Online] 2 (1), 75-92. Available from: doi:10.1111/j.1523-1739.1988.tb00337.x.

Sparovek, G., Berndes, G., Oliveira Pereira Barretto, A.G. de \& Klug, I.L.F. (2012) The revision of the Brazilian Forest Act: increased deforestation or a historic step towards balancing agricultural development and nature conservation?. Environmental Science \& Policy. [Online] 16, 65-72. Available from: doi:10.1016/j.envsci.2011.10.008.

Temple, S.A. \& Cary, J.R. (1988) Modeling Dynamics of Habitat-Interior Bird Populations in Fragmented Landscapes. Conservation Biology. [Online] 2 (4), 340-347. Available from: 
doi:10.1111/j.1523-1739.1988.tb00198.x.

Thompson, F.R. (2007) Factors affecting nest predation on forest songbirds in North America. Ibis. [Online] 149, 98-109. Available from: doi:10.1111/j.1474-919x.2007.00697.x.

Tilman, D., May, R.M., Lehman, C.L. \& Nowak, M.A. (1994) Habitat destruction and the extinction debt. Nature. [Online] 371 (6492), 65-66. Available from: doi:10.1038/371065a0. Vetter, D., Rücker, G. \& Storch, I. (2013) A meta-analysis of tropical forest edge effects on bird nest predation risk:. Biological Conservation. [Online] 159, 382-395. Available from: doi:10.1016/j.biocon.2012.12.023.

Weidinger, K. (2008) How well do predation rates on artificial nests estimate predation on natural passerine nests?. Ibis. [Online] 143 (3), 632-641. Available from: doi:10.1111/j.1474919x.2001.tb04891.x.

Whitehouse, N.J. \& Smith, D. (2010) How fragmented was the British Holocene wildwood? Perspectives on the "Vera" grazing debate from the fossil beetle record. Quaternary Science Reviews. [Online] 29 (3-4), 539-553. Available from: doi:10.1016/j.quascirev.2009.10.010.

Whyte, B.I., Didham, R.K. \& Briskie, J.V. (2005) The effects of forest edge and nest height on nest predation in two differing New Zealand forest habitats. New Zealand Natural Sciences. 30 .

Wilcove, D.S., McLellan, C.H. \& Dobson, A.P. (1986) Habitat fragmentation in the temperate zone. Conservation biology. 6, 237-256.

Wolf, M. \& Batzli, G.O. (2002) Effects of forest edge on populations of white-footed mice Peromyscus leucopus. Ecography. [Online] 25 (2), 193-199. Available from: doi:10.1034/j.16000587.2002.250207.x.

Yahner, R.H. \& Mahan, C.G. (1999) Potential for predator learning of artificial arboreal 
nest locations. The Wilson Bulletin. 111, 536-540.

Yahner, R.H. \& Mahan, C.G. (1996) Depredation of Artificial Ground Nests in a Managed Forested Landscape. Conservation Biology. [Online] 10 (1), 285-288. Available from: doi:10.1046/j.1523-1739.1996.10010285.x.

Yahner, R.H. \& Scott, D.P. (1988) Effects of Forest Fragmentation on Depredation of Artificial Nests. The Journal of Wildlife Management. [Online] 52 (1), 158. Available from: doi:10.2307/3801078.

Zanette, L. (2002) What do artificial nests tells us about nest predation?. Biological Conservation. [Online] 103 (3), 323-329. Available from: doi:10.1016/s0006-3207(01)00143-4. 